\title{
ANALISIS RENCANA PEMASANGAN TRANSFORMATOR SISIPAN PADA SALURAN TRANSFORMATOR DISTRIBUSI PENYULANG PAGUTAN (Studi Kasus: Transformator Distribusi AM097Di Jalan Banda Seraya, Pagesangan, Kota Mataram)
}

\author{
An Analysis of Insertion Transformer Installation Plan on Distribution Transformer - Line \\ In Pagutan Feeder (Case Study: Distribution Transformer of AM097 On Banda Seraya \\ Street, Pagesangan, Mataram City) \\ Ni Made Seniari ${ }^{1}$, M. Najmul Fadli ${ }^{2}$, I Made Ginarsa ${ }^{3}$ \\ ${ }^{1}$ Jurusan Teknik Elektro, Fakultas Teknik Universitas mataram, NTB \\ Email: ${ }^{1}$ seniari nimade@unram.ac.id, ${ }^{2}$ mnajmulfadli@gmail.com, ${ }^{3}$ kadekgin@unram.ac.id
}

\begin{abstract}
ABSTRAK
Data lapangan menunjukkan pembebanan Transformator Distribusi AM097 di Jalan Banda Seraya Pagutan, Kota Mataram, sudah overload sebesar 92,82\%, tegangan pelanggan paling ujung bernilai $183,85 \mathrm{~V}$, rugi daya saluran $15,87 \mathrm{~kW}$. Drop tegangan mencapai $25,10 \%$ melebihi batas yang diizinkan dalam SPLN No.72 tahun 1987, yaitu drop tegangan maksimal 5\%. Untuk memperbaiki kondisi jaringan maka dilakukan analisis rencana pemasangan transformator sisipan menggunakan simulasi ETAP. Dengan memperhatikan penempatan transformator sisipan pada jarak $313,18 \mathrm{~m}$ dari transformator utama, beban transformator utama $69,16 \%$, transformator sisipan kapasitas $100 \mathrm{kVA}$ dibebani 45,64\%. Hasil simulasi menunjukkan tegangan di ujung beban $222,3 \mathrm{~V}$, drop tegangan $3,16 \%$, dan rugi daya saluran sebesar $4,16 \%$.
\end{abstract}

Kata Kunci :Drop tegangan, rugi daya saluran, Transformator sisipan.

\begin{abstract}
The field data shows that loading at AM097 Distribution Transformer at Banda Seraya Pagutan Street, Mataram City, are overloaded by $92.82 \%$. The tip customer voltage is 183,85 V, line power loss is $15.87 \mathrm{~kW}$. The drop voltage reaches $25.10 \%$, this is beyond the limit that allowed in SPLN No.72 of 1987 with maximum value of $5 \%$. To stabilize the network condition, an analysis of insertion transformer installation plan using ETAP simulation are required. Taking into account to the placement of the insertion transformer at $313.18 \mathrm{~m}$ from the main transformer, the main transformer is $100 \mathrm{kVA}$ and $45.64 \%$ loaded. After the simulation started, the tip customer voltage we get is $222.3 \mathrm{~V}$, drop voltage is $3.16 \%$, and line power loss of 4.16 $\%$.
\end{abstract}

Keywords : drop voltage, line power loss, insertion transformer.

\section{PENDAHULUAN}

Sistem ketenaga listrikan terus mengalami perkembangan, salah satunya adalah pertambahan pelanggan atau beban energi listrik dari tahun ke tahun. Sistem pendistribusian tenaga listrik memerlukan keandalan tinggi. Akan tetapi, sering terjadi permasalahan yang timbul pada pendistribusian ketenagalistrikan. Salah satunya adalah pembebanan transformator distribusi yang sudah melebihi kapasitas atau dapat dikatakan transformator overload Transformator dikatakan overload jika kapasitas pembebanannya lebih dari $80 \%$.. Overload pada transformator distribusi menyebabkan terjadinya drop (jatuh) tegangan, dan drop tegangan ini akan di transfer menjadi panas pada belitan dan pada inti trafo. Apabila hal ini terjadi dalam waktu yang lama, maka isolasi cair dan isolasi padat transformator mengalami panas yang berlebihan, dan dapat memperpendek umur isolasi trafo, bahkan trafo dapat mengalami kerusakan total.

Terdapat dua metode alternatif untuk mengatasi permasalahan transformator overload, yaitu dengan metode pemasangan transformator sisipan dan upratting (peningkatan kapasitas). Transformator overload terjadi pada transformator distribusi 200 kVA, AM097 di PT. PLN (Persero) Area Mataram wilayah kerja Rayon Ampenan,. 
Persentase pembebanannya telah mencapai $92,82 \%$ dan drop tegangan ujung tertinggi sebesar $25,10 \%$. Transforator overload dan jatuh tegangan yang tinggi, mengharuskan dilakukan tindakan terhadap transformator distribusi tersebut. Dengan memperhatikan letak beban maka tindakan yang tepat dilakukan adalah dengan pemasangan transformator sisipan. Upratting transformator hanya mengganti transformator yang sudah ada dengan kapasitas di naikkan, tetapi, belum dapat mengatasi drop tegangan di ujung saluran secara maksimal.

Dalam penelitian ini, dilakukan analisa terhadap rencana pemasangan transformator sisipan di Transformator Distribusi AM097. Diharapkan dengan penelitian ini, didapatkan perencanaan yang baik, dan mampu meningkatkan keandalan sistem distribusi listrik di Jaringan Tegangan Rendah (JTR) di Transformator Distribusi AM097.

\section{LANDASAN TEORI}

\section{Sistem Distribusi Sekunder}

Kadir (2000), menyatakan sistem distribusi sekunder digunakan untuk menyalurkan tenaga listrik dari gardu distribusi ke beban-beban yang ada di konsumen. Sistem distribusi sekunder ini menerima daya listrik dari transformator distribusi, serta mendistribusikan daya tersebut ke konsumen. Mengingat bagian ini berhubungan langsung dengan konsumen, maka kualitas listrik harus dalam kondisi bagus.

Saluran distribusi sekunder menggunakan kabel yang berisolasi maupun konduktor tanpa isolasi. Sistem ini biasanya disebut sistem tegangan rendah yang langsung dihubungkan dengan konsumen (pemakai tenaga listrik).

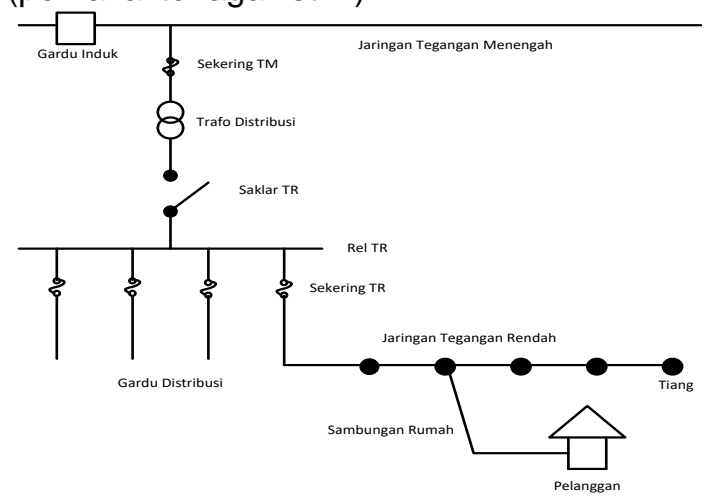

Gambar 1. Hubungan Tegangan Menengah ke Tegangan Rendah

\section{Transformator Distribusi Sisipan}

Transformator sisipan merupakan transformator tambahan yang dipasang oleh PT. PLN untuk menanggulangi berbagai kerugian yang ditimbulkan oleh transformator sebelumnya. Perbedaan transformator sisip dan transformator pasang baru adalah, jika transformator sisip hanya mengambil beban transformator sebelumnya, sedangkan transformator pasang baru adalah memasang transformator baru karena adanya permintaan baru atau penggantian transfoirmator karena rusak, atau karena kapasitas trafonya dinaikkan. .

Beberapa faktor yang dipertimbangkan oleh PT. PLN untuk menambah transformator sisipan adalah :Transformator sebelumnya sudah overload

dan besarnya drop tegangan pada JTR. Menurut PT. Perusahaan Listrik Negara (PT. PLN), 1987, tertuang dalam SPLN No. 72 pasal 4 ayat 19 tentang Pengaturan Tegangan dan Turun Tegangan, bahwa jatuh tegangan yang diperbolehkan pada transformator distribusi adalah $3 \%$ dari tegangan kerja, dan jatuh tegangan pada STR dibolehkan sampai $5 \%$ dari tegangan kerja.

Untuk menentukan kapasitas transformator sisipan yang dapat di perlukan menggunakan persamaan :

$$
\text { KapasitasTrafo }=\frac{[\text { KVA Deban (KVA)] }}{0,8}
$$

Penempatan transformator distribusi sisipan jarak ideal dari transformator distribusi pertama adalah :

$$
\mathrm{L} \text { ideal }=\frac{1036 \times \mathrm{V} \text { Ive }}{I \text { Beban Puncakxh saluran }}
$$

\section{Pembebanan Transformator}

Menurut PT. PLN, 1997, yang tertuang dalam SPLN No. 50, transformator distribusi diusahakan tidak dibebani lebih dari $80 \%$ atau dibawah $40 \%$. Jika melebihi atau kurang dari nilai tersebut transformator bisa dikatakan overload atau underload. Diusahakan agar transformator tidak dibebani keluar dari range tersebut.

Perhitungn KVA beban dan prosentase beban transformator adalah sebagai berikut (Kadir, 2000).

kVA beban $=\left(I_{R} \times V_{R-N}\right)+\left(I_{S} \times V_{S-N}\right)+\left(I_{T} \times V_{T-N}\right)$

$\%$ beban Transformator $=\frac{\text { KVA Beban }}{\text { KVA Trafo }} \times 100 \%$

\section{Tegangan Jatuh}

Tegangan jatuh (drop voltage) atau rugi tegangan adalah perbedaan tegangan kirim 
dan tegangan terima karena adanya impedansi pada penghantar. Adapun penyebab jatuh tegangan yang paling berpengaruh adalah :

1.Panjang jaringan, jauhnya jaringan dari transformator.

2. Rendahnya tegangan yang diberikan dari transformator distribusi.

3. Jenis penghantar yang digunakan.

4.Sambungan penghantar atau konektor yang tidak baik.

5. Arus yang dihasilkan terlalu besar.

Menurut PT. Perusahaan Listrik Negara (PT. PLN), 1987, tertuang dalam SPLN No. 72 pasal 4 ayat 19 tentang Pengaturan Tegangan dan Turun Tegangan, bahwa jatuh tegangan yang diperbolehkan pada transformator distribusi $3 \%$ dari tegangan kerja. Turun tegangan pada STR dibolehkan sampai $5 \%$ dari tegangan kerja.

Persentase drop tegangan dapat dihitung melalui persamaan berikut (Kadir, 2000) :

$$
\mathrm{V}_{\text {drop }}(\%)=\left(\frac{V_{s}-V_{T}}{V_{T}}\right) \times 100 \%
$$

dimana :

$$
\begin{aligned}
& \mathrm{V}_{\text {drop }}(\%)=\text { drop tegangan }(\%) \\
& \mathrm{V}_{\mathrm{S}}=\text { tegangan } \operatorname{kirim}(\mathrm{V}) \\
& \mathrm{V}_{\mathrm{R}} \quad=\text { tegangan terima }(\mathrm{V})
\end{aligned}
$$

\section{Rugi Daya}

Rugi daya saluran timbul karena adanya komponen resistansi dan reaktansi saluran dalam bentuk rugi daya aktif dan reaktif. Rugi daya aktif yang timbul pada komponen resistansi saluran distribusi akan terdisipasi dalam bentuk energi. Rugi daya dicari menggunakan rumus (Kadir, 2000):

Dimana :

$$
\Delta \mathrm{P}=\frac{1}{3}\left(\mathrm{I}_{\mathrm{R}}{ }^{2+} \mathrm{I}_{\mathrm{S}}{ }^{2+} \mathrm{I}_{\mathrm{T}}{ }^{2+} \mathrm{I}_{\mathrm{N}}{ }^{2}\right) \times R \times L
$$

$$
\begin{aligned}
& \Delta P=\text { Rugi daya }(W) \\
& I_{R}=\operatorname{Arus~fasa~} R(A) \\
& I_{S}=\operatorname{Arus~fasa~} S(A) \\
& I_{T}=\operatorname{Arus~fasa~} T(A) \\
& I_{N}=\text { Arus Netral }(A) \\
& R=\text { Resistansi saluran }(\Omega)
\end{aligned}
$$

\section{Resistansi Penghantar}

Resistansi adalah kemampuan suatu material penghantar dalam menghambat arus listrik. Resistansi ini menyebabkan kerugian daya pada saluran distribusi

\section{METODE PENELITIAN}

Penelitian perencanaan pemasangan transformator sisipan ini melalui tahapan pengumpulan data, perhitungan, simulasi, dan analisa. Pengumpulan data dilakukan di PT. PLN (Persero) Rayon Ampenan
Transformator Distribusi AM097, dengan terlebih dahulu melalui tahapan permintaan izin pengambilan data. Setelah data terkumpul dilakukan perhitungan besar pembebanan, besar drop tegangan, besar rugi daya pada transformator distribusi. Selanjutnya melakukan simulasi menggunakan ETAP 12.6.0 versi student untuk mendapatkan nilai pembebanan dan nilai tegangan ujung transformator setelah dilakukannya pemasangan transformator sisipan. Analisa dilakukan untuk mendapatkan perbandingan nilai pembebanan, nilai tegangan ujung, dan rugi daya sebelum dan sesudah dilakukannya rencana pemasangan transformator sisipan.

Tabel 1. Karakteristik Twisted Kabel Aluminium (PT. PLN, 2010)

\begin{tabular}{ccccc}
\hline \multirow{4}{*}{$\begin{array}{c}\text { Ukuran } \\
\text { Kabel } \\
\left(\mathrm{mm}^{2}\right)\end{array}$} & $\begin{array}{c}\mathrm{R} \\
(\Omega / \mathrm{km} \\
\end{array}$ & $\begin{array}{c}\text { KHA } \\
(\mathrm{A})\end{array}$ & $\begin{array}{c}\mathrm{X} \\
(\Omega / \mathrm{km})\end{array}$ & $\begin{array}{c}\text { Resistansi } \\
(\Omega / \mathrm{km})\end{array}$ \\
\hline $2 \times 10$ & 3,08 & 54 & 0,168 & 3,08 \\
\hline $2 \times 16$ & 1,91 & 72 & 0,138 & 1,91 \\
\hline $2 \times 25$ & 1,2 & 130 & 0,124 & 1,38 \\
\hline $2 \times 35$ & 0,868 & 125 & 0,116 & 1,38 \\
\hline $2 \times 50$ & 0,641 & 154 & 0,106 & 0,986 \\
\hline $3 \times 70$ & 0,443 & 196 & 0,103 & 0,69 \\
\hline $3 \times 95$ & 0,32 & 242 & 0,098 & 0,45 \\
\hline
\end{tabular}

\section{Diagram Alir Penelitian}

Diagram alir penelitian dapat dilihat pada Gambar 2.

\section{HASIL DAN PEMBAHASAN \\ Analisis Beban Transformator Utama}

Beban trafo distribusi AM097 menunjukkan pembebanan yang terus meningkat dari waktu ke waktu. Hal ini diakibatkan adanya penambahan jumlah pelanggan listrik, ataupun adanya penambahan daya yang dilakukan oleh pelanggan. Bahkan pembebanan

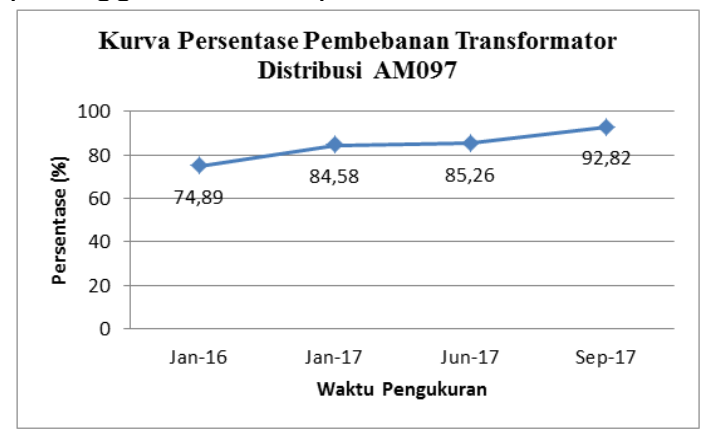

Gambar 3. Kurva pembebanan Transformator AM097 (PT. PLN, 2017) 


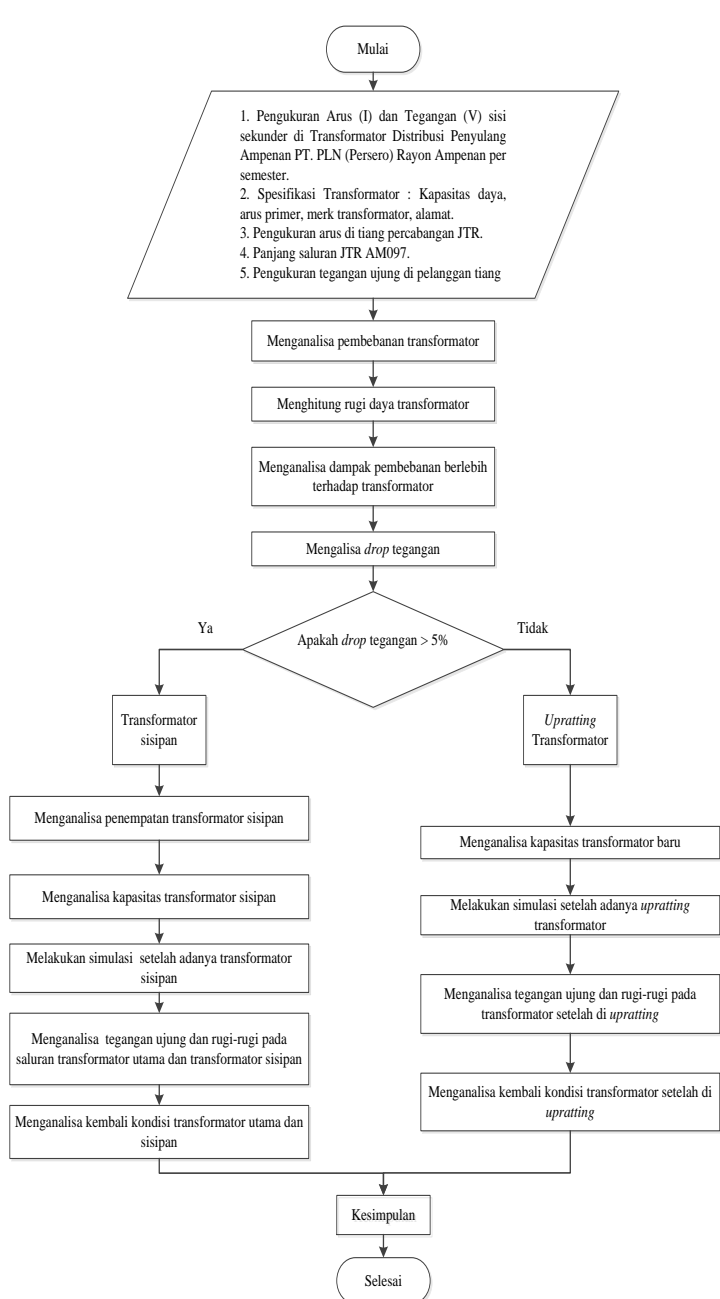

Gambar 2. Diagram Alir Penelitian

transformator telah mencapai $92,82 \%$ saat pengukuran bulan September 2017. Jadi transformator Distribusi AM097 ini dinyatakan telah mengalami overload (pembebanan lebih).

\section{Data Pengukuran Transormator AM097 sebelum Rencana Transformator Sisipan}

Transformator Distribusi AM097 merupakan jenis gardu tipe portal terdiri dari 2 jurusan yaitu jurusan A dan C. Tabel 2 menunjukkan pengukuran tegangan sisi sekunder trafo, dan tabel 3 menunjukkan pengukuran arus beban. Tabel 4 menunjukkan pengukuran arus di setiap tiang percabangan. Pengukuran dilakukan tanggal 5 September 2017 pukul 21:04 WITA :

\section{Analisis Tata Letak Transformator Sisipan}

Dari pengukuran arus total pada Tabel 3 , yaitu arus fasa $R, S, T$ masing-masing: 233 , 324, 306A. Sehingga nilai arus rerata maksimal :

$$
\text { Irerata }=\frac{\left(I_{R}+I_{S}+I_{T}\right)}{a}
$$

$$
\begin{aligned}
& =\frac{(233+324+306)}{3} \\
& =287,67 \mathrm{~A}
\end{aligned}
$$

Letak yang ideal dalam penempatan transformator sisipan dari transformator utama dihitung dengan persamaan.

$L$ ideal

$$
\begin{aligned}
& =\overline{I \text { Beban Puncak (revata) } R \text { saluran }} \\
& =\frac{1076 \times 400}{287,67 \times 0,443} \\
& =0,31388 \mathrm{~km}
\end{aligned}
$$

Tabel 2. Pengukuran tegangan sisi sekunder transformator

\begin{tabular}{ccccccc}
\hline \multirow{2}{*}{ Daya } & \multicolumn{6}{c}{ Pengukuran Tegangan } \\
\cline { 2 - 7 } & RN & SN & TN & RS & ST & RT \\
\hline $\begin{array}{c}200 \\
\text { kVA }\end{array}$ & 214 & 216 & 215 & 376 & 377 & 377 \\
\hline
\end{tabular}

Tabel 3. Pengukuran arus sisi sekunder transformator

\begin{tabular}{cccc}
\hline \multicolumn{4}{c}{ PENGUKURAN ARUS BEBAN (A) } \\
\hline \multirow{2}{*}{ FASA } & \multicolumn{3}{c}{ LINE / JURUSAN } \\
\cline { 2 - 4 } & $\mathrm{A}$ & $\mathrm{C}$ & TOTAL \\
\hline $\mathrm{R}$ & 143 & 86 & 233 \\
\hline $\mathrm{S}$ & 179 & 128 & 324 \\
\hline $\mathrm{T}$ & 205 & 101 & 306 \\
\hline $\mathrm{N}$ & 82 & 73 & 153 \\
\hline
\end{tabular}

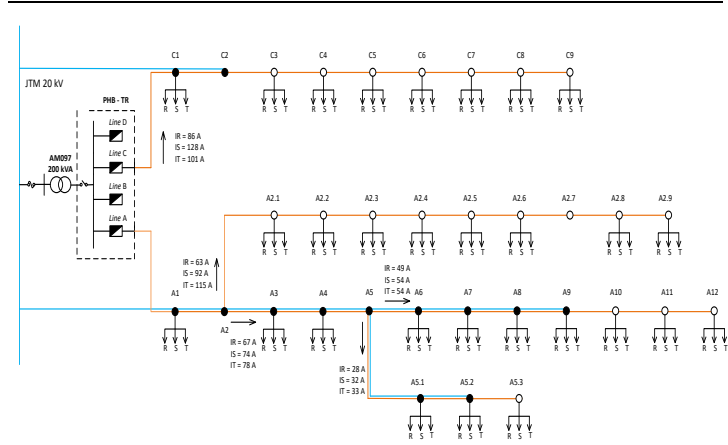

Gambar 4. Hasil pengukuran arus di tiang percabangan saluran

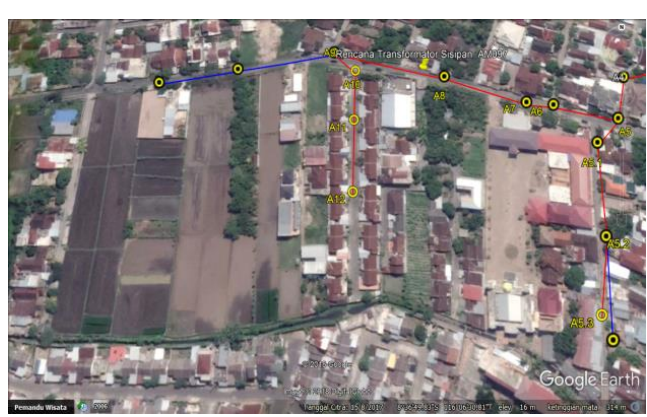

Gambar 5. Peta rencana penempatan transformator sisipan AM097 
Transformator sisipan ditempatkan di antara tiang Gawang A8-A9 dengan rincian : jarak antara transformator sisipan dengan tiang A9 (Garsip AM097 - A9) = 56,83 m; dan jarak antara transformator sisipan dengan tiang A8 (Garsip AM097 - A8) = 16,22 m; dengan koordinat $8^{\circ} 36^{\prime} 46.94 " S \quad 116^{\circ}$ 6'32.82"T. Beberapa hal yang menjadi pertimbangan adalah sebagai berikut :

1.Tegangan ujung terendah terjadi pada ujung beban tiang $\mathrm{A} 12$ dengan tegangan sebesar : fasa R, S, T masing-masing = 185,2: 184,$5 ; \quad 183,85$ V. Sehingga penempatan transformator sisipan harus dekat dengan tiang A12 untuk menaikkan tegangan ujung tiang.

2.Saluran JTM yang terdekat dengan tiang A12 adalah gawang A8-A9. Sehingga dalam penempatan transformator sisipan tidak perlu menambah jaringan tiga fasa untuk menyuplai tegangan $20 \mathrm{kV}$ ke transformator sisipan.

3. Rencana penempatan transformator sisipan juga dekat dengan lahan kosong, yang memungkinkan pengembangan jaringan atau gawang baru disaat yang akan dating dapat di lihat dari gambar 5 .

4. Jarak antara transformator AM097 dengan rencana transformator sisipan dapat memenuhi jarak ideal seperti perhitungan yaitu sebesar $313,18 \mathrm{~m}$. Karena dalam perancangan ini jarak transformator distribusi AM097 ke transformator sisipan tepat berjarak $313,18 \mathrm{~m}$.

\section{Perhitungan Kapasitas Transformator Sisipan}

Gambar 1 memperlihatkan besar persentase pembebanan transformator yang menggunakan data pengukuran terakhir yaitu sebesar 92,82\%. Sedangkan persentase beban maksimal yang diperbolehkan PT. PLN adalah $80 \%$. Sehingga dapat dihitung juga kelebihan bebannya yaitu :

$$
\begin{aligned}
\text { Kelebihan beban } & =92,82 \%-80 \% \\
& =12,82 \%
\end{aligned}
$$

Sedangkan kelebihan beban $12,82 \%$ dari 200 kVA adalah:

$$
\begin{aligned}
\text { Kelebihan beban } & =\left(\frac{12,82 \%}{100 \%}\right) \times 200 \\
& =25,64 \mathrm{kVA}
\end{aligned}
$$

Akan tetapi, dalam perancangannya beban maksimal yang tersisa di transformator utama tidak boleh $80 \%$ melainkan $70 \%$.

Jadi beban trafo utama yang di ambil alih oleh trafo sisipan yaitu : $\left(\left(92,82 \% \times 200.10^{3}\right)\right.$ $\left.-\left(70 \% \times 200.10^{3}\right)\right)=45,64$ kVA.
Dengan pertimbangan penambahan jumlah pelanggan, pertambahan beban yang terus meningkat, serta nilai susut umur transformator yang relative rendah, maka pemilihan kapasitas transformator sisipan yang direncanakan sebesar $100 \mathrm{kVA}$. Jadi daya yang di tanggung trafo sisipan 45,64 kVA atau 45,64\% dari total kapasitas 100 kVA.

\section{Perhitungan Pembebanan Transformator}

Setelah dilakukannya simulasi penempatan transformator sisipan maka Transformator AM097 tidak lagi memikul beban seperti semula. Karena sebagian bebannya telah dipindahkan ke transformator sisipan. Beban yang tersisa pada transformator utama $200 \mathrm{KVA}$ adalah $70 \%$ dari kapasitasnya, yaitu sebesar 138,326 kVA. Sehingga persentase pembebannya trafo utama yang terbaru dapat dihitung dengan persamaan sebagai berikut :

$$
\begin{aligned}
\% \text { beban } & =\frac{\text { KVA Beban }}{\text { kVA TYKaf }} \times 100 \% \\
& =\frac{138.226}{200} \times 100 \% \\
& =69,16 \%
\end{aligned}
$$

Berdasarkan hasil perhitungan diatas bahwa persentase pembebanan transformator AM097 menurun dari 92,82 \% menjadi $69,16 \%$ atau mendekati $70 \%$.

\section{Analisa Perbandingan JTR Transformator Distribusi AM097 Sebelum dan Sesudah Adanya Rancangan Transformator Sisipan.}

\section{Perbandingan Rugi Daya.}

Diketahui bahwa JTR Transformator Distribusi AM097 menggunakan penghantar LVTC $3 \times 7+1 \times 50 \mathrm{~mm}^{2}$ dengan nilai resistansi penghantar $(R)=0,443 \Omega / \mathrm{km}$. Panjang total jurusan $A=0,915 \mathrm{~km}$ dan jurusan $C=0,379$ $\mathrm{km}$. Nilai arus untuk masing-masing jurusan dapat dilihat pada Tabel 3. Perhitungan rugi daya total per jurusan dilakukan dengan persamaan berikut :

$$
\begin{aligned}
& \Delta \mathrm{P} \text { jurusan } \mathrm{A}=\frac{1}{3}\left(\mathrm{I}_{\mathrm{R}}{ }^{2+} \mathrm{I}_{\mathrm{S}}{ }^{2+} \mathrm{I}_{\mathrm{T}}{ }^{2+} \mathrm{I}_{\mathrm{N}}{ }^{2}\right) \times R \times L \\
& =\frac{1}{3}\left(143^{2+} 179^{2+} 205^{2+} 82^{2}\right) \times 0,443 \times 0,915 \\
& =\frac{1}{3}(101239) \times 0,405 \\
& =13667,265 \mathrm{~W} \\
& \triangle \mathrm{P} \text { jurusan } \mathrm{C}=\frac{1}{3}\left(\mathrm{I}_{\mathrm{R}}{ }^{2+} \mathrm{I}_{\mathrm{S}}{ }^{2+} \mathrm{IT}_{\mathrm{T}}{ }^{2+} \mathrm{I}_{\mathrm{N}}{ }^{2}\right) \times R \times L \\
& =\frac{1}{3}\left(86^{2+} 128^{2+} 101^{2+} 73^{2}\right) \times 0,443 \times 0,379 \\
& =\frac{1}{3}(39310) \times 0,168 \\
& =2201,36 \mathrm{~W} \\
& \triangle \mathrm{P} \text { total }=\Delta \mathrm{P} \text { jurusan } \mathrm{A}+\triangle \mathrm{P} \text { jurusan } \mathrm{C} \\
& =13667,265 \mathrm{~W}+2201,36 \mathrm{~W}
\end{aligned}
$$




$$
=15868,625 \mathrm{~W}
$$$$
=15,87 \mathrm{~kW}
$$

Jadi rugi-rugi daya total pada JTR Transformator Distribusi AM097 sebesar $15,87 \mathrm{~kW}$.

Setelah run program simulasi ETAP 12.6.0, nilai arus pada tiap jurusan mengalami perubahan setelah adanya transformator sisipan. Sehingga rugi-rugi daya pada jaringan juga mengalami perubahan. Tabel 4 berikut adalah hasil perhitungan rugi-rugi daya sebelum dan sesudah dipasangnya transformator sisipan :

Tabel 4.Perbandingan rugi-rugi daya

\begin{tabular}{cccccc}
\hline \multicolumn{2}{c}{$\begin{array}{c}\Delta P \text { Jurusan } A \\
(\mathrm{~kW})\end{array}$} & \multicolumn{2}{c}{$\begin{array}{c}\Delta \mathrm{P} \text { Jurusan } \\
(\mathrm{kW})\end{array}$} & \multicolumn{2}{c}{$\Delta \mathrm{P}$ Total $(\mathrm{kW})$} \\
\hline $\begin{array}{c}\text { Belu } \\
\text { m }\end{array}$ & $\begin{array}{c}\text { Suda } \\
\mathrm{h}\end{array}$ & $\begin{array}{c}\text { Belu } \\
\mathrm{m}\end{array}$ & $\begin{array}{c}\text { Suda } \\
\mathrm{h}\end{array}$ & $\begin{array}{c}\text { Belu } \\
\mathrm{m}\end{array}$ & $\begin{array}{c}\text { Suda } \\
\mathrm{h}\end{array}$ \\
\hline 13,67 & 2,65 & 2,2 & 1,51 & 15,87 & 4,16 \\
\hline
\end{tabular}

Grafik 6 berikut menunjukkan nilai rugirugi daya sebelum dan sesudah adanya transformator sisipan. Nilai rugi-rugi daya berkurang setelah adanya transformator sisipan. Penurunan paling signifikan terjadi di jurusan A. Hal ini disebabkan karena transformator sisipan dirancang dipasang di jurusan $A$, dan sebagian beban di jurusan $A$ dialihkan ke transformator sisipan. Sehingga nilai arus yang mengalir pada jurusan A berkurang.

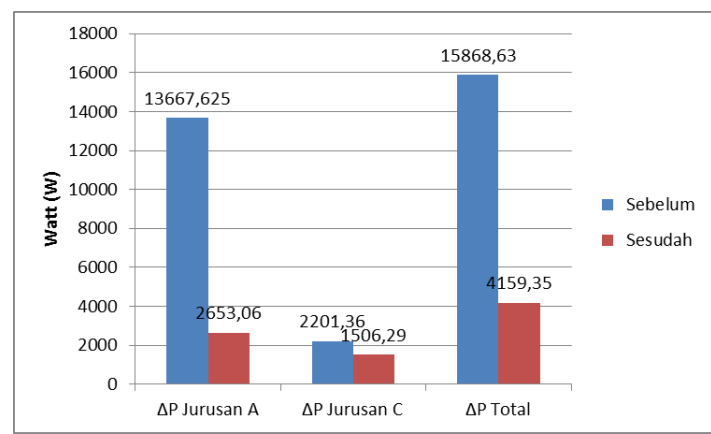

Gambar 6.Grafik perbandingan rugi-rugi daya sebelum dan sesudah adanya transformator sisipan.

Faktor lain yang berpengaruh terhadap penurunan nilai rugi-rugi daya adalah panjang total saluran JTR yang sudah berkurang. Setelah adanya transformator sisipan panjang total saluran pada jurusan $A$ sebesar 0,445 $\mathrm{km}$, yang pada awalnya panjang totalnya sebesar $0,915 \mathrm{~km}$. Perhitungan rugi-rugi daya berbanding lurus dengan nilai panjang saluran tiap jurusan. Sehingga saat nilai panjang saluran berkurang, maka nilai rugirugi daya pun ikut berkurang.

Tabel 5.Perbandingan tegangan ujung dan drop tegangan sebelum dan sesudah adanya transformator sisipan

\begin{tabular}{|c|c|c|c|c|c|c|}
\hline \multirow{2}{*}{ Jurusan } & \multirow{2}{*}{ Tiang } & \multirow{2}{*}{ Fasa } & \multicolumn{2}{|c|}{ Tegangan Ujung (V) } & \multicolumn{2}{|c|}{ Drop Tegangan (\%) } \\
\hline & & & Sebelum & Sesudah & Sebelum & Sesudah \\
\hline \multirow{9}{*}{$A$} & \multirow{3}{*}{ A2.9 } & $\mathrm{R}$ & 192 & 205,3 & 19,79 & 12,03 \\
\hline & & $S$ & 190,85 & 205 & 20,51 & 12,20 \\
\hline & & $\mathrm{T}$ & 189,7 & 204,7 & 21,24 & 12,36 \\
\hline & \multirow{3}{*}{ A5.3 } & $\mathrm{R}$ & 196,7 & 216,8 & 16,93 & 6,09 \\
\hline & & $S$ & 195,5 & 216,6 & 17,65 & 6,19 \\
\hline & & $\mathrm{T}$ & 197,95 & 216,6 & 16,19 & 6,19 \\
\hline & \multirow{3}{*}{ A12 } & $\mathrm{R}$ & 185,2 & 222,3 & 24,19 & 3,46 \\
\hline & & $S$ & 184,5 & 222,3 & 24,66 & 3,46 \\
\hline & & $\mathrm{T}$ & 183,85 & 222,3 & 25,10 & 3,46 \\
\hline \multirow{3}{*}{$\mathrm{C}$} & \multirow{3}{*}{ C9 } & $\mathrm{R}$ & 195,8 & 204 & 17,47 & 12,75 \\
\hline & & $S$ & 194,95 & 203,6 & 17,98 & 12,97 \\
\hline & & $\mathrm{T}$ & 195,4 & 203,9 & 17,71 & 12,80 \\
\hline
\end{tabular}

Tegangan ujung setelah adanya transformator sisipan didapatkan dari hasil simulasi ETAP. Gambar 7 berikut adalah contoh hasil simulasi tegangan ujung di tiang ujung : Untuk contoh perhitungan drop tegangan dapat dihitung data pada tiang A12 sebelum adanya transformator sisipan Perhitungan drop tegangan Fasa $R$, dengan nilai $V s=230 \mathrm{~V}$ dan $\mathrm{Vr}=192 \mathrm{~V}$ : 


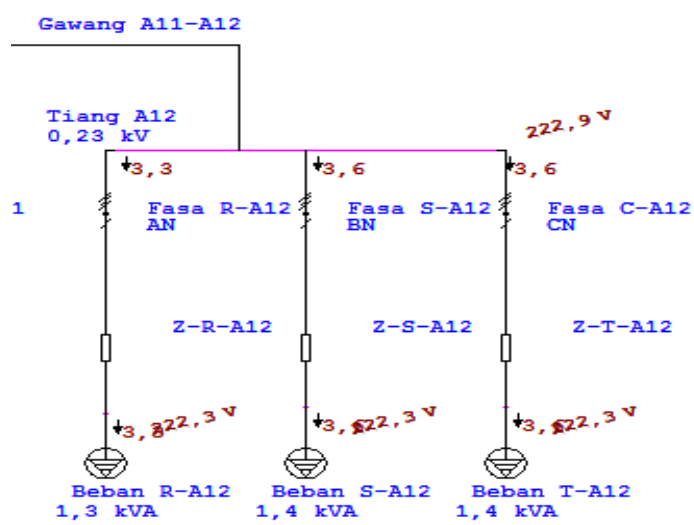

Gambar 7. Hasil simulasi ETAP tegangan ujung pelanggan jurusan $A$ (setelah ada transformator sisipan)

$$
\begin{aligned}
\mathrm{V}_{\mathrm{R}}(\%) & =\left(\frac{\mathrm{V}_{\mathrm{K}}-\mathrm{V}_{\mathrm{T}}}{\mathrm{V}_{\mathrm{I}}}\right) \times 100 \% \\
& =\left(\frac{230-192}{192}\right) \times 100 \% \\
& =19,79 \%
\end{aligned}
$$

Perhitungan drop tegangan Fasa $\mathrm{S}$, dengan nilai $V s=230 \mathrm{~V}$ dan $\mathrm{Vr}=190,85 \mathrm{~V}$ :

$$
\begin{aligned}
V_{S}(\%) & =\left(\frac{V_{s}-V_{T}}{V_{T}}\right) \times 100 \% \\
& =\left(\frac{230-190,85}{190,85}\right) \times 100 \% \\
& =20,51 \%
\end{aligned}
$$

Perhitungan drop tegangan Fasa $\mathrm{T}$, dengan nilai $V s=230 \mathrm{~V}$ dan $\mathrm{Vr}=189,7 \mathrm{~V}$ :

$$
\begin{aligned}
V_{\mathrm{T}}(\%)= & \left(\frac{V_{s}-V_{T}}{V_{T}}\right) \times 100 \% \\
& =\left(\frac{230-189.7}{189.7}\right) \times 100 \% \\
& =21,24 \%
\end{aligned}
$$

Untuk perhitungan selanjutnya ditunjukkan pada Tabel 5 ..

Tabel 5 memperlihatkan bahwa terjadi perubahan nilai tegangan ujung dan drop tegangan sesudah adanya transformator sisipan. Perbandingan nilai tegangan ujung sebelum dan sesudah adanya transformator sisipan diperlihatkan Gambar 9.

Gambar 8 menunjukkan perbandingan nilai drop tegangan sebelum dan sesudah adanya transformator sisipan. Terlihat terjadi peningkatan nilai tegangan ujung di setiap fasa, baik di jurusan A maupun jurusan C. Pada saluran beban tiang A2.9, dan saluran beban tiang $\mathrm{C} 9$ terjadi peningkatan nilai tegangan ujung, walaupun bebannya tidak termasuk ke dalam beban yang dialihkan ke

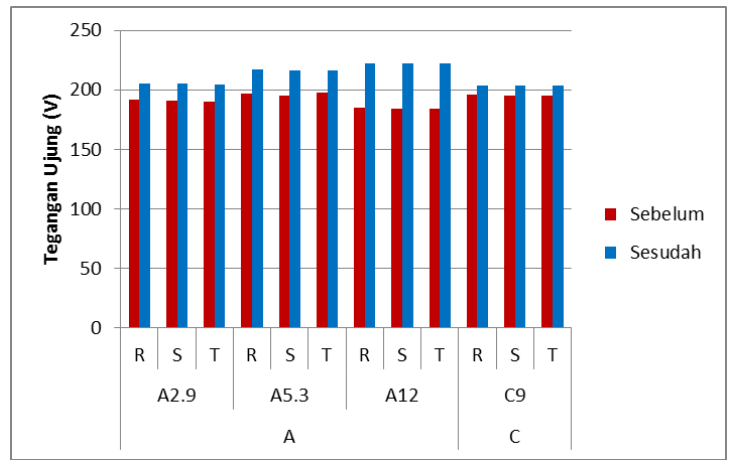

Gambar 8.Perbandingan tegangan ujung sebelum dan sesudah adanya transformator sisipan

transformator sisipan. Pada beban tiang A5.3 dan beban tiang A12 terjadi pengingkatan nilai tegangan ujung yang signifikan, karena beban saluran di kedua tiang tersebut yang dialihkan ke transformator sisipan.

Peningkatan tegangan ujung tertinggi terjadi di tiang A12, karena sebelum adanya transformator sisipan, nilai tegangan ujungnya bernilai paling rendah. Kemudian sesudah adanya transformator sisipan, nilai tegangan ujungnya bernilai paling tinggi. Hal ini juga dikarenakan transformator sisipan berada paling dekat dengan beban ujung saluran tiang A12. Sehingga yang paling terpengaruh dengan adanya transformator sisipan adalah tegangan ujung tiang $\mathrm{A} 12$ tersebut.

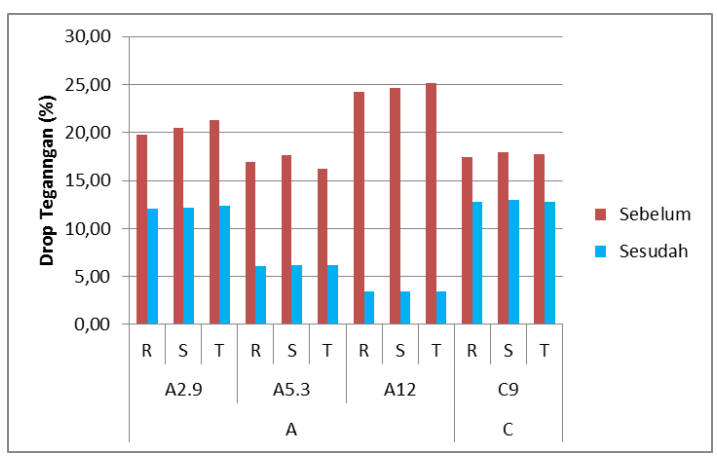

Gambar 9. Perbandingan drop tegangan sebelum dan sesudah adanya transformator sisipan

Gambar 9 memperlihatkan nilai drop tegangan berkurang setelah adanya transformator sisipan, baik di jurusan $\mathrm{A}$ maupun di jurusan C. Penurunan nilai drop tegangan ini terjadi karena meningkatnya nilai tegangan pada setiap tiang ujung, seperti Gambar 8. Gambar 9 menunjukkan bahwa penurunan drop tegangan secara signifikan terjadi di tiang ujung A5.3 dan tiang ujung A12. Hal ini disebabkan oleh beban saluran tiang ujung A5.3 dan tiang ujung A12 dialihkan ke transformator sisipan.Sehingga nilai drop tegangan di kedua tiang ujung 
tersebut paling terpengaruh oleh adanya transformator sisipan.

Gambar 9 dan table 5, menunjukkan nilai drop, sesudah adanya transformator sisipan nilai drop tegangan pada beban ujung saluran masih berada di atas $5 \%$. Akan tetapi, dengan adanya transformator sisipan,

dapat menurunkan nilai drop tegangan pada beban ujung saluran. Hanya beban tiang ujung $\mathrm{A} 12$ yang drop tegangannya berada di bawah $5 \%$, yaitu sebesar $3,46 \%$ di tiap fasanya. Hal ini disebabkan karena pada saat perancangan letak transformator sisipan, sedekat mungkin dengan tiang ujung yang mengalami drop tegangan tertinggi.

\section{KESIMPULAN}

Dari pembahasan dan analisisis, dapat disimpulkan beberapa hal sebagai berikut :

1. Letak transformator sisipan di JTR Transformator Distribusi AM097 yaitu di antara tiang $\mathrm{A} 8$ dan $\mathrm{A} 9$, dekat dengan lahan kosong yang memungkinkan pengembangan jaringan disaat yang akan datang.

2. Besar beban yang tersisa untuk Transformator utama AM097 sebesar 138,326 kVA dengan kapasitas transformator 200 kVA. Sedangkan beban yang dialihkan ke transformator sisipan adalah 45,64 kVA dengan kapasitas transformator $100 \mathrm{kVA}$.

3. Adanya penambahan transformator sisipan pada JTR Transformator Distribusi AM097 berpengaruh terhadap beberapa hal, diantaranya :

a. Pembebanan pada Transformator Distribusi AM097 mengalami penurunan dari $92,82 \%$ menjadi $69,16 \%$, karena adanya pembagian beban ke transformator sisipan. Sehingga dengan persentase pembebanan 69,16\% Transformator Distribusi AM097 tidak lagi mengalami overload.

b. Nilai rugi daya total pada saluran JTR Transformator Distribusi AM097 mengalami penurunan yang signifikan, dengan nilai rugi daya menjadi 4159,35 W.

c. Pemasangan transformator sisipan pada Transformator Distribusi AM097 dapat meningkatkan tegangan ujung, dari 183,85 V menjadi 222,3 V.

d. Persentase drop tegangan pada ujung beban Transformator Distribusi AM097 setelah adanya transformator sisipan adalah $3,46 \%$. Nilai ini masih dalam ketentuan regulasi tegangan PLN.

\section{SARAN}

1. Perlu adanya koordinasi yang baik antara pemerintah terkait dengan pihak PLN berkenaan dengan perencanaan beban di daerah tersebut. Hal ini bertujuan agar kebutuhan listrik di masyarakat dapat 2 diprediksi sedini mungkin.

erkaitan dengan penempatan transformator sisipan sebaiknya tidak hanya mengandalkan perhitungan saja, namun tetap dilakukan survei lokasi untuk mempertimbangkan pertumbuhan dan perkembangan beban untuk beberapa tahun ke depan agar mendapatkan hasil yang lebih baik bagi PLN maupun masyarakat.

\section{DAFTAR PUSTAKA}

[1] Kadir, A., 2000, Distribusi dan Utilisasi Tenaga Listrik, Universitas Indonesia : Jakarta.

[2] PT. PLN (Persero), SPLN No. 72 Tahun 1987, Pengaturan Tegangan dan Turun Tegangan.

[3] PT. PLN (Persero), SPLN No. 50 Tahun 1977, Spesifikasi Transformator Distribusi.

[4] PT. PLN (Persero), 2010, Buku 1 : Kriteria Disain Enjinering Konstruksi Jaringan Distribusi Tenaga Listrik, PT. PLN : Jakarta Selatan.

[5] PT. PLN (Persero), 2017, Laporan Pemeratan Beban Gardu Ampenan. AREA Mataram Rayon Ampenan : Mataram. 